\title{
Disruption of the sporulation-specific gene spiA in Dictyostelium discoideum leads to spore instability
}

\author{
Delwood L. Richardson and William F. Loomis \\ Department of Biology, University of California San Diego, La Jolla, California 92093-0322 USA
}

The spiA gene of Dictyostelium is expressed specifically in prespore cells and spores during culmination, the final stage of development during which prespore and prestalk cells undergo terminal differentiation to form spores and stalk. We have used homologous recombination to delete this gene and have characterized the resulting phenotype. The spi ${ }^{-}$strains develop normally and produce spores that are indistinguishable from those of wild-type strains by transmission and scanning electron microscopy. Mutant spores have normal viability when assayed soon after the completion of development, but, as the spiA $^{-}$spores age, they lose viability more rapidly than those of the spiA ${ }^{+}$parent. The drop in viability is more pronounced when spores are submerged in dilute buffer at a concentration that does not allow germination; after 11 days submerged, the viability of spiA ${ }^{-}$spores is $10^{5}$-fold reduced, whereas that of the parent is decreased only 10-fold. Reinserting an intact copy of the spiA gene into a spiA ${ }^{-}$strain restores the stability of its spores. The product of the spiA gene, Dd31, was identified on Western blots as a 30-kD protein using an antibody raised against a fusion protein containing a portion of the coding sequence. Dd31 is associated with the inner face of spore coat fragments in a detergent-resistant manner. This location is consistent with its observed role in maintaining stability of the spores.

[Key Words: Homologous recombination; culmination; spore viability]

Received January 15, 1992; revised version accepted March 18, 1992.

Most of the cells in the fruiting body of Dictyostelium discoideum are spores that can lie dormant and survive inhospitable conditions. Spores are produced during culmination, a process in which an aggregate of prespore and prestalk cells undergoes a defined set of morphological changes and terminal cytodifferentiations that give rise to a ball of spores held aloft on a cellular stalk (Loomis 1975). The stalk tube is synthesized as prestalk cells migrate into it from the top, where they rapidly differentiate into stalk cells by synthesizing a cellulose shell and vacuolizing (George et al. 1972). At the same time, the prespore cells differentiate into spores while moving up the growing stalk. Prespore cells contain prespore vesicles in which the spore coat proteins SP60, SP70, and SP96 accumulate prior to culmination (Orlowski and Loomis 1979; Devine et al. 1983; Erdos and West 1989|. To sporulate, the prespore cells dehydrate and the prespore vesicles fuse with the plasma membrane to release the spore coat components /Hohl and Hamamoto 1969). These components assemble to form the inner and outer layers of the coat; a middle cellulose layer is synthesized and deposited between the two proteinaceous layers (West and Erdos 1990). This process results in spores that are resistant to heat and desiccation (Cotter and Raper 1968).

A germination inhibitor, discadenine, is present in the interspore fluid, which prevents the spores from germinating until it is washed away upon dispersal (Cohen and Ceccarini 1967; Abe et al. 1976). For spores to germinate, they must escape from the spore coat, which both protects and imprisons them. Spores that have been washed free of discadenine can be activated by amino acids, heating, or treatment with dimethylsulfoxide (Cotter and Raper 1968). After activation, the spore coat swells and eventually ruptures along one side (Cotter et al. 1969). During the swelling phase, cellulases are synthesized and released (Jones et al. 1979; Blume and Ennis 1991); they presumably digest portions of the cellulose wall to weaken the spore coat and allow its breakage. Four to six hours after activation, after dissolving the inner layer of the three layer coat, the amoebas emerge from the spore coat (Cotter et al. 1969).

Expression of the spiA gene (known previously as Dd31) correlates with sporulation during development (Richardson et al. 1991). Accumulation of the spiA mRNA is observed in prespore cells and spores during culmination but not in amoebas or prestalk or stalk cells. The timing of its expression is restricted and closely linked to the morphology of the culminant, commencing as the ball of prespore amoebas is approximately one-half way up the newly formed stalk $1 \sim 22 \mathrm{hr}$ of development). The spiA mRNA accumulates rapidly 
and then apparently drops off (Richardson et al. 1991). Mutants blocked at early stages of development do not express spiA message. Strains carrying the homeotic mutation stkA (stalky) develop normally up to culmination, but the prespore cells then differentiate into stalk cells (Morrissey et al. 1981). stkA mutants do not express spiA message or produce spores during culmination, indicating that spiA expression is coupled to the induction of sporulation (Richardson et al. 1991). Neither sporulation nor spiA expression of cells dissociated from early culminants can be induced by cAMP, but both are induced by $8-\mathrm{Br}$-cAMP, which penetrates the cell and is thought to act by increasing intracellular cAMP levels (Kay 1989; Richardson et al. 1991). The spiA gene product, as predicted from its DNA sequence, is a $31-\mathrm{kD}$ protein containing four hydrophobic regions, which has no significant homology with any protein described previously (Richardson et al. 1991). Mapping of the Dictyostelium genome has placed the locus spiA on chromosome 7 adjacent to csaA (Kuspa et al. 1992).

We have used homologous recombination to replace the spiA gene with a partially deleted, inactive copy. Development of the spiA- strains proceeds normally to produce spores that are initially indistinguishable from wild type. However, we found that the stability of the spores is compromised, and the viability of mutant spores drops dramatically as they age. The instability of the mutant spores is mediated by their exposure to water, because they remained stable when stored dry. Reintroduction of the intact gene into the mutant restores the wild-type phenotype, confirming that the phenotype results from the lesion in spiA. We have identified the spiA gene product, Dd31, using an antibody to a fusion protein containing part of the spiA-coding region. It is a $30-\mathrm{kD}$ protein that accumulates during culmination and is a component of the mature spore. A simple fractionation of the spore proteins indicates that $\mathrm{Dd} 31$ is associated with spore coat fragments produced by disrupting spores. Dd31 is not solubilized by a number of detergents that should solubilize any membrane present, but it is solubilized by SDS without the addition of reducing agents. Analysis of spore coat fragments and intact spores with the antibody in situ indicates that $\operatorname{Dd} 31$ is on the inner face of the spore coat.

\section{Results}

\section{Disruption of the spiA gene}

To allow replacement of the spiA gene with a defective copy, we constructed the vector pKD31-3 (Fig. 1) in which a $3.7-\mathrm{kb}$ fragment containing the UMP synthase gene (pyr5-6) replaced $450 \mathrm{bp}$ of the coding sequence of spiA within the 4-kb genomic insert of pLG4 (see Materials and methods). pKD31-3 contains 1.4 and $2.2 \mathrm{~kb}$ of $D$. discoideum genomic DNA flanking the deletion in the spiA gene to facilitate homologous recombination. pKD31-3 linearized with BgII was electroporated into the pyr5-6- Ax-2-derived $D$. discoideum strain HL310 (see Materials and methods). BglI cuts twice in the pGEM-
$3 \mathrm{Zf}(-)$ portion of the vector, outside of the Dictyostelium sequence, leaving 0.2 and $1.4 \mathrm{~kb}$ of vector DNA at the $5^{\prime}$ and $3^{\prime}$ ends, respectively. Transformants were selected for the ability to grow in minimal media in the absence of uracil, which requires integration of DNA containing the pyr5-6 gene, and were plated on bacteria at a concentration to allow the isolation of single colonies as described in Materials and methods (Kalpaxis et al. 1990, 1991).

Southern analysis of genomic DNA from eight transformants indicated that six of the eight had the spiA gene replaced with the pyr5-6 gene $175 \%$ homologous recombination; data not shown). Two of the strains carrying gene replacements, which were not siblings because they were selected from different transformation plates, were chosen for further characterization. Genomic DNA from parent (HL310) and transformants (HL351 and HL352) was digested with EcoRI, Southern blotted, and probed with a nick-translated 560-bp HindIII-EcoRI fragment that remains at the $3^{\prime}$ end of the disrupted gene (see Fig. 1). The 1-kb EcoRI band recognized by the probe in the parent is shifted to $4.3 \mathrm{~kb}$ in the gene replacement strains, as expected after replacement of $0.45 \mathrm{~kb}$ of the spiA gene with a 3.7-kb fragment containing pyr5-6 (Fig. 2A). Probing the same blot for pyr5-6 yielded a new band at $4.3 \mathrm{~kb}$ in the transformants in addition to the $>12-\mathrm{kb}$ band containing the endogenous mutant copy, which was present in all three strains (Fig. 2B). The relative intensities of the two bands that hybridize to the pyr5-6 probe indicate that the replacement copy is present in two or fewer copies. Other studies suggest that the pyr5-6 gene often inserts as a single copy (Kalpaxis et al. 1991), and the lower intensity of the upper band may be the result of less efficient transfer of the larger DNA from the gel to the Nytran filter. Probing a parallel blot with the 450-bp fragment, which was removed from spiA in pKD31-3, showed that this sequence was missing in the transformants HL351 and HL352 (data not shown).

To remove any question about the effect of a particular genetic background on any observed phenotype, we also disrupted the gene in an Ax-4 background. BamHI/BglIlinearized $\mathrm{pKD} 31-3$ was electroporated into the $\mathrm{Ax}$-4-derived pyr5-6- $6^{-}$strain HL328. BamHI removes the $0.2 \mathrm{~kb}$ of vector DNA from the $5^{\prime}$ end of the spiA gene that is left by just cutting with BgII (see above and Fig. 1). Transformants were selected as described above, and they were screened for the loss of the 450-bp fragment of spiA by genomic dot blot as described in Materials and methods. Of the 19 transformants selected, 13 had lost the fragment $168 \%$ homologous recombination; data not shown). Two strains, HL356 and HL357, were chosen for further characterization. Genomic Southern blots confirmed that the spiA gene was disrupted, because the $1-\mathrm{kb} E$ EcoRI band was replaced with a $4.3-\mathrm{kb}$ band as was observed with the Ax-2-derived strains in Figure $2 \mathrm{~A}$ /data not shown).

Characterization of the spi $A^{-}$strains

Morphogenesis of the spiA- ${ }^{-}$strains HL351 and HL352 


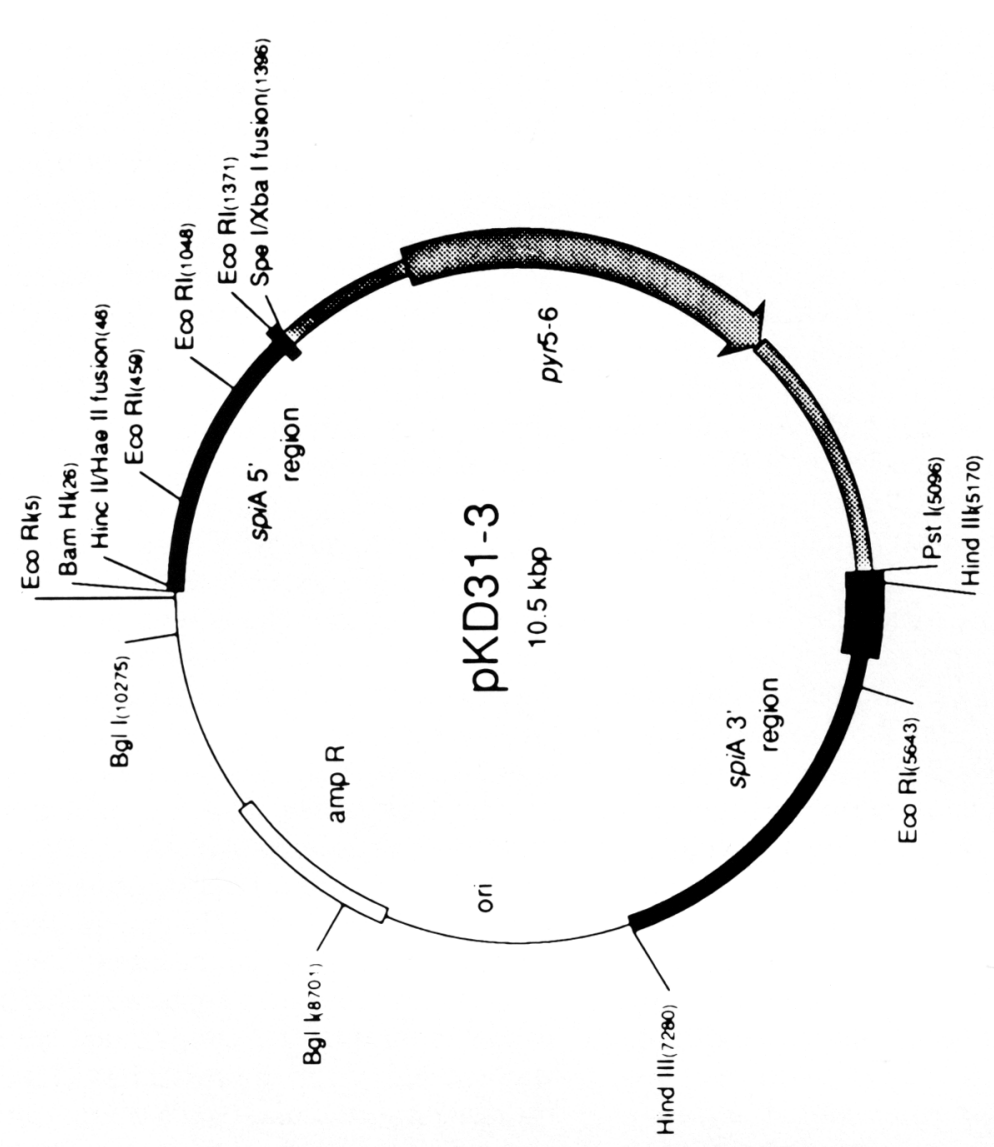

오웛

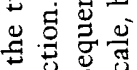

s

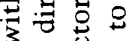

品

些下矛

뭉

o $0 \sum^{\infty}$

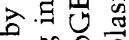

을

苟焉

임

ज्ञ 옹 워

竞兘

U.

a

近吉亚

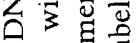

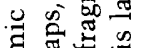

踏

$\infty$

ป

고ㅇㅝㅛ

递

$\therefore \underset{0}{0} \overrightarrow{0}$

$\stackrel{4}{4}$

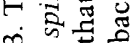

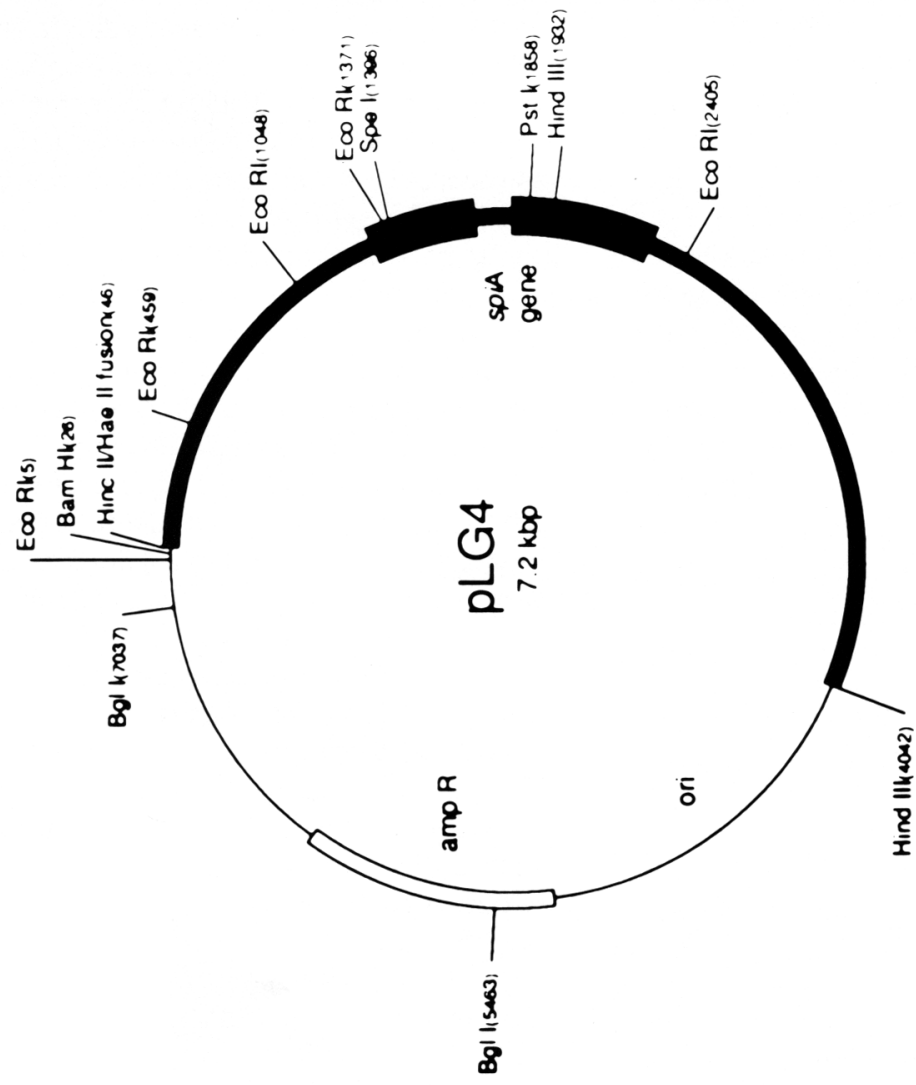

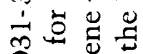

苟造表

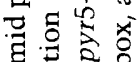

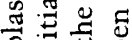

르응

苞

द्

颀

워

过

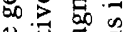

苛

可跑

古至起

正为远

$0 \div$

द्व

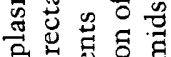

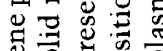

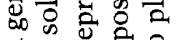

结起方

का

造苛

웡

我舟

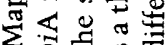

का

-

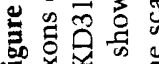

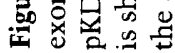



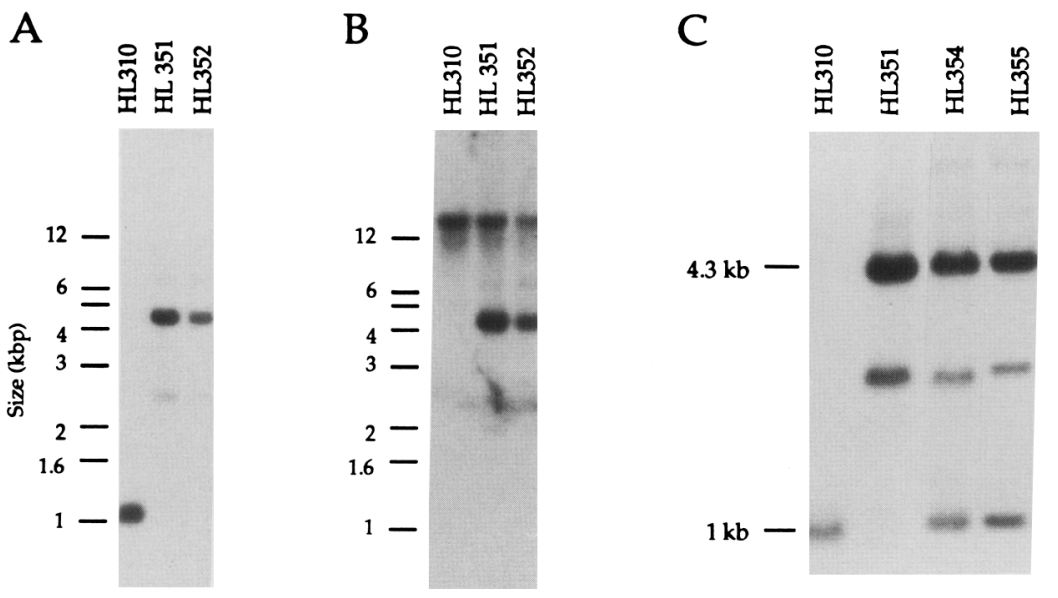

Figure 2. Southern analysis of transformed strains. Genomic DNA from the indicated strains was isolated by the genomic miniprep procedure and digested with EcoRI (see Materials and methods $).(A, B)$ Comparison of the parental strain HL310 with the spiA ${ }^{-}$strains HL351 and HL352; $(C)$ demonstration of the rescue of spiA ${ }^{-}$ strain HL351 to form the spiA ${ }^{+}$strains HL354 and HL355. $A$ and $C$ were probed with a labeled 560 -bp HindIII-EcoRI fragment from the right half of spiA, which is present in the vector pKD31-3 (see Fig. 1); $B$ was probed with a labeled 3.7-kb HindIII fragment from DIV-1 containing the pyr5-6 gene.

on filters appeared normal through culmination. The timing of appearance of the various stages was identical to that in the parental strain HL310, and the fruiting bodies were of the same shape and size. Northern analysis of RNA collected at 2-hr intervals during culmination indicated that the spiA mRNA did not accumulate in strain HL351 (Fig. 3) and HL352 (data not shown). Fresh spores of strain HL351 were indistinguishable from those of strain HL310 by scanning electron microscopy (Fig. 4, top) and transmission electron microscopy of thin sections (Fig. 4, bottom).

Viability of wild-type and spiA ${ }^{-}$spores was similar if assayed soon after development was complete (Fig. 5A, 0 days). However, if spores were left on the stalks for a week or more, the viability of the mutant spores dropped more rapidly than that of the parent (Fig. 5A). The viability on the stalk was rather variable, perhaps owing to variations in the population of sori selected off the plate for each day's experiment. In addition to the change in viability, inspection of old spores by phase contrast microscopy revealed that $85 \%$ of the mutant spores were phase dark after 15 days while only $50 \%$ of the spores from the parent strain were phase dark at that point.

Spores are inhibited from germinating while retained in sori on top of the stalks by the germination inhibitor,

\section{HL310 (spiA $\left.{ }^{+}\right)$}

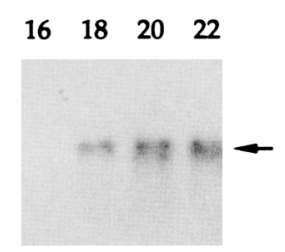

\section{HL351 (spiA $\left.{ }^{-}\right)$}

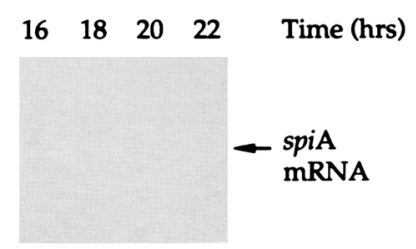

Figure 3. Developmental Northern blot of spiA mRNA. Northern blots were prepared from the parental strain (HL310) and a mutant transformant (HL351) and probed for spiA mRNA as described previously by Richardson et al. (1991). The position of spiA mRNA is indicated and was confirmed by comparison to that of culmination stage Ax-4 RNA. discadenine, that accumulates during late development (Loomis 1975; Abe et al. 1976). It seemed possible that the loss of viability of spiA- mutant spores might be related to premature germination within sori as the result of reduced accumulation of discadenine or a reduced sensitivity to the inhibitor. To test this possibility, spores of strains HL310 (spiA $\left.{ }^{+}\right)$, HL351 (spiA $\left.{ }^{-}\right)$, and HL352 (spiA ${ }^{-}$) were collected from sori and diluted in phosphate buffer to either $10^{7}$ or $10^{8}$ spores $/ \mathrm{ml}$. After incubation for 2 days at room temperature, $20-40 \%$ of the spores of each of the strains had germinated in the populations diluted to $10^{7}$ spores $/ \mathrm{ml}$ while $<2 \%$ had germinated in the populations diluted to $10^{8}$ spores $/ \mathrm{ml}$. After continued incubation for up to 2 weeks, germination was still $<10 \%$ in the concentrated populations. These observations indicated that the spiA ${ }^{-}$strains both accumulated the inhibitor and responded to it as well as the wild-type strain.

Because dew collects in sori as they age, we postulated that the premature loss of viability of spiA ${ }^{-}$spores could result from uptake of water. Analysis of the viability of spores submerged at $10^{8} / \mathrm{ml}$ over the 2-week period revealed that the viability of the mutant spores dropped 100,000 -fold while that of wild-type spores dropped only 10 -fold (Fig. 5B). The viability of spores from the Ax-4derived spiA ${ }^{-}$strains HL356 and HL357 also dropped 50,000 -fold after 12 days submersion while the viability of the parent strain HL328 dropped $<10$-fold (data not shown).

For long-term storage, Dictyostelium spores are traditionally dried in lyophils (lyophilization tubes) and sealed under vacuum, after which they are stable for at least 40 years (Sussman 1987). To examine the longevity of these spores when stored in dry conditions, we prepared lyophils with spores from spiA ${ }^{-}$(HL351) and spi ${ }^{+}$parent (HL310) strains and examined spore viability at intervals up to 5 months (Fig. $5 \mathrm{C}$ ). Recovery of viable wild-type spores from the tubes was $\sim 10 \%$ of the input, whereas that of the $s p i \mathrm{~A}^{-}$spores was $\sim 2 \%$ during the first month. Recovery of viable spiA- spores decreased gradually thereafter but at a much slower rate 

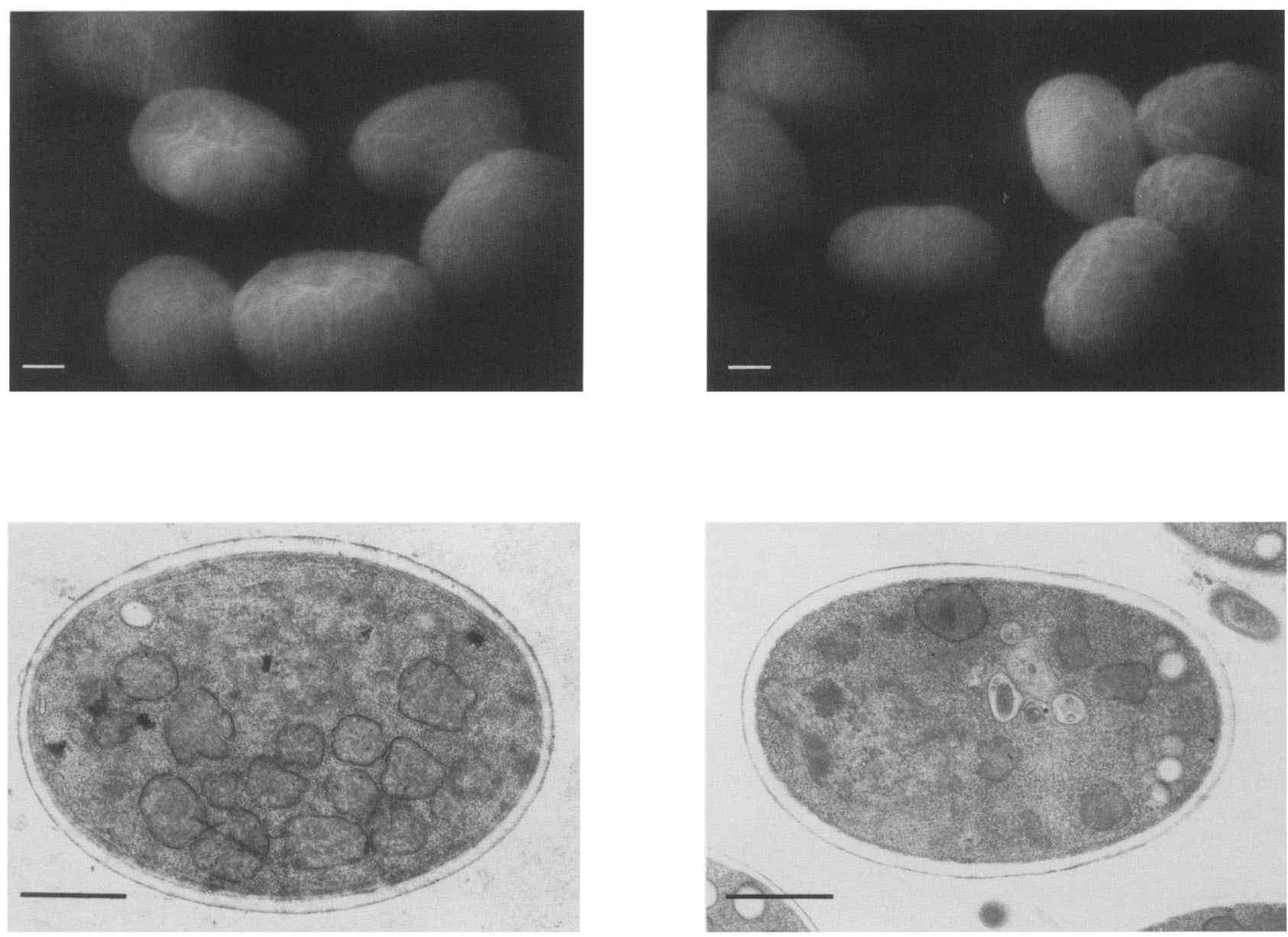

Figure 4. Electron micrographs of spores from spiA ${ }^{+}($left $)$and $\operatorname{spiA}^{-}($right $)$strains. Top panels show scanning electron micrographs of spores; bottom panels are transmission electron micrographs of embedded and sectioned spores (see Materials and methods). Bars, $1 \mu \mathrm{m}$.

than observed with submerged spores (cf. Fig. 5B). It appears that loss of spore viability either in sori while still on the stalk or submerged in buffer results from drowning of the mutant spores.

\section{Alterations in spore structure during drowning}

spiA- ${ }^{-}$spores that were exposed to water, either in a dew drop on the stalk or submerged in dilute buffer, gradually made a transition from phase bright to phase dark. Midway in this transition, when the spores were phase gray, they appeared to be swollen, much in the way that spores appear during germination. Electron micrographs of a spiA $^{-}$spore that had remained on the stalk for 8 days revealed that the middle layer was significantly thicker than that of a normal spore (Fig. 6A). Other spores observed at this time were normal (see Fig. 4, bottom right). However, swollen coats were rarely seen in micrographs of spores of the spiA ${ }^{+}$strain (data not shown). The defect in spiA ${ }^{-}$spores was dramatically observed in electron micrographs of spores that were submerged for 17 days; while the majority of the spi $\mathrm{A}^{+}$spores appeared normal
(Fig. 6B), the mutant spores had swollen spore coats and disordered interiors (Fig. 6C).

\section{Replacement of the spiA gene and characterization of the rescued strains}

To confirm that the mutant spore phenotype resulted from the lesion in spiA, we reintroduced a functional copy of the gene. A pyr5-6- derivative of HL351HL353-was created by plasmid-mediated gene conversion using DIV-1 (see Materials and methods; Kalpaxis et al. 1991). Transformants were selected and analyzed by Southern blots to confirm the spiA ${ }^{-}$pyr5-6- $6^{-}$genotype. A rescue vector, $\mathrm{pLG} 4 \mathrm{Pyr}$, was constructed by cloning the $3.7-\mathrm{kb}$ fragment containing pyr5-6 into the multiple cloning site of pLG4 (Fig. 1), next to, but not interfering with, the spiA gene (see Materials and methods). It was used to transform HL353, and each of the eight ura ${ }^{+}$ transformants tested contained an integrated copy of the plasmid (data not shown). Southern analysis of two of the transformants, HL354 and HL355, showed that both 
A

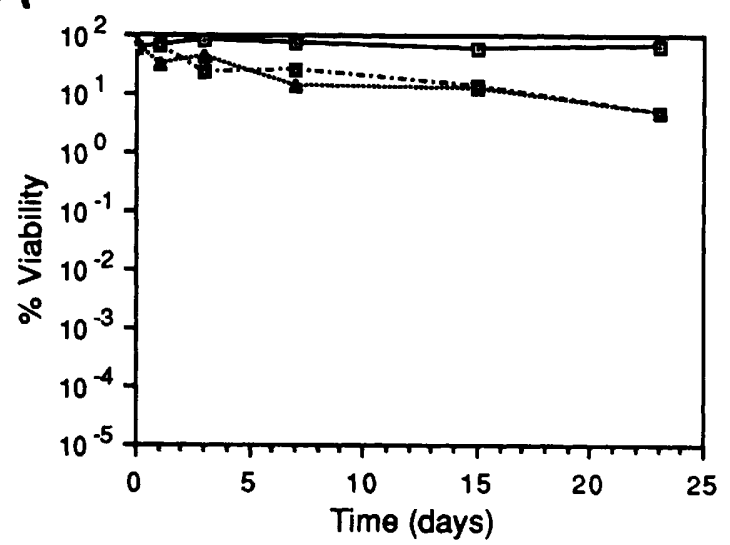

Q

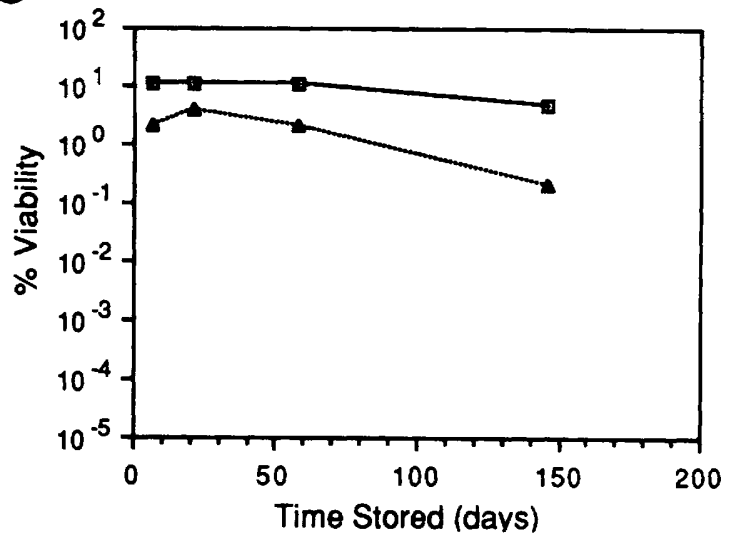

B

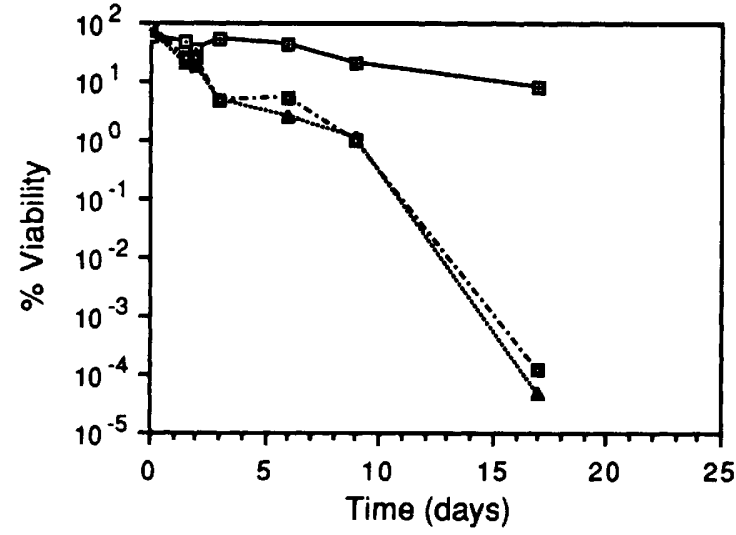

D

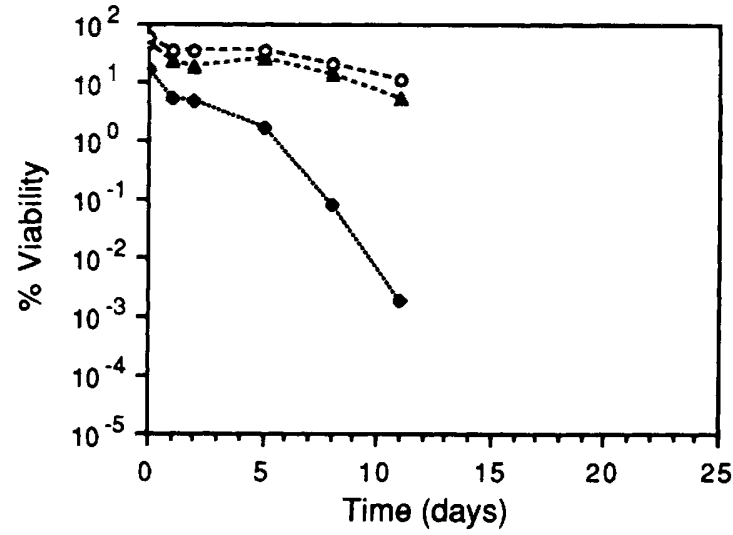

Figure 5. Spore viability over time. The viability of spores of each strain was determined as described in Materials and methods while $A$ remained on stalks after development on filters, $B$ and $D$ submerged in 0.1 mm sodium potassium phosphate $(\mathrm{pH} 6.4)$ at $1.5 \times 10^{8}$ spores $/ \mathrm{ml}$ without washing, or $C$ stored dry in lyophils (note eightfold difference in time scale). The strains tested are the spiA ${ }^{+}$parent

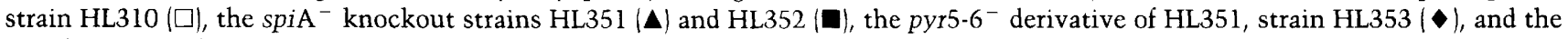
spiA $^{+}$rescues of HL353, strains HL354 ( $\triangle$ ) and HL355 (O).

contain the new copy of spiA in addition to the original deleted copy (Fig. 2C).

Developmental Northern blots were prepared for the rescued strains HL354 and HL355 and probed for spiA mRNA (Fig. 7). Both strains accumulated the spiA message, and the temporal expression of spiA mRNA in the rescued strains was identical to that in the spiA + "greatgrandparent" HL310 (cf. Fig. 3). As expected, no spiA mRNA accumulated during development of the spiA ${ }^{-}$ pyr5-6- strain HL353 (data not shown).

Spore stability was also restored to the spiA ${ }^{-}$strains by the introduction of a functional copy of the spiA gene (Fig. 5D). While the pyr5-6 ${ }^{-}$derivative of HL351HL353-showed the same dramatic loss of viability as the parent strain, both of the rescued strains, HL354 and HL355, were as stable as wild-type strains when submerged over a 2 -week period at high density (cf. Fig. 5B). Therefore, the sensitivity of spiA ${ }^{-}$spores to death by drowning is directly attributable to the lesion in the spiA gene.
Identification of the spiA gene product, $D d 31$

A portion of the spiA gene was fused to the T7 gene 10 protein and overexpressed in Escherichia coli as described in Materials and methods. SDS-PAGE-purified fusion protein was then used to produce polyclonal antibodies in rabbits (see Materials and methods). The resultant antibody (506-3) recognized a single polypeptide of $\sim 30 \mathrm{kD}$ on a Western blot of protein samples from a developmental time course (Fig. 8). Sera from the same rabbit collected prior to immunization with the fusion protein (506-0) did not bind to any proteins over the same developmental time course (data not shown). Comparison of spore proteins from spiA ${ }^{+}$and spiA ${ }^{-}$strains by Western blot probed with 506-3 showed that the presence of the $30-\mathrm{kD}$ band is limited to strains containing a functional copy of the spiA gene (Fig. 9A).

The $30-\mathrm{kD}$ protein was first detected at $24 \mathrm{hr}$ and continued to accumulate until culmination was complete at $28 \mathrm{hr}$ (Fig. 8). The protein was still present in mature 

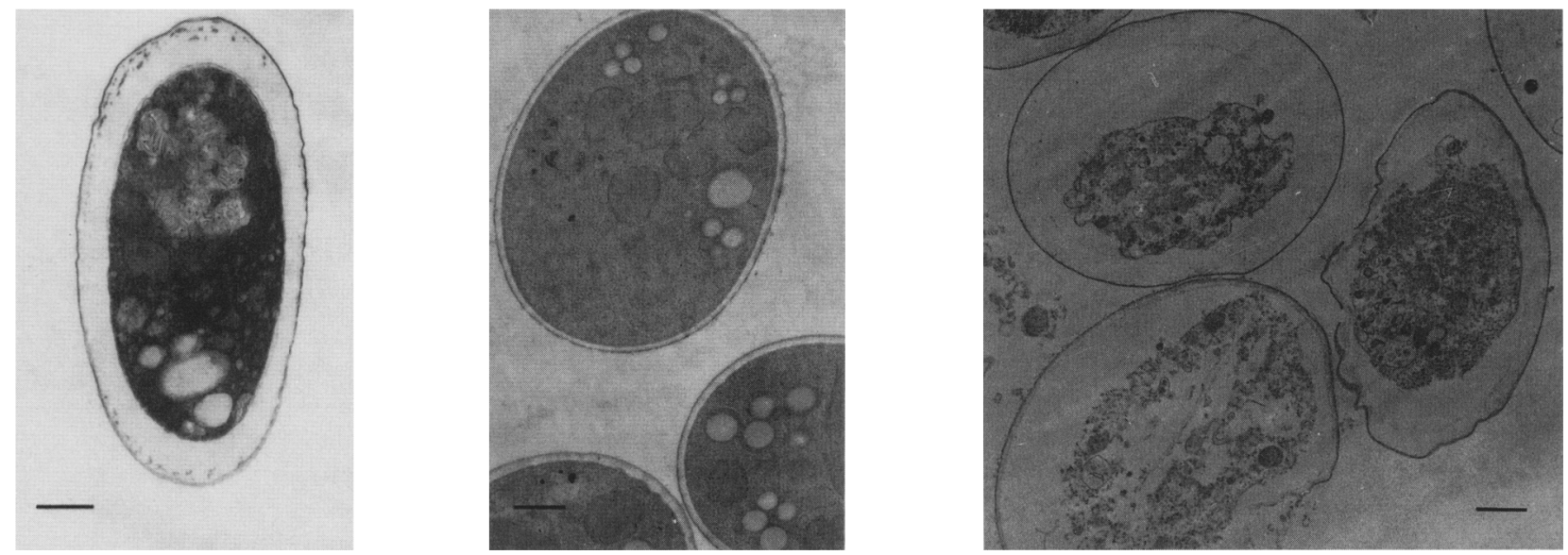

Figure 6. Transmission electron micrographs of aged spores. (A) Swollen spiA (HL351) spore after 8 days on the stalk. The population contains spores such as this, as well as normal spores (see Fig. 4, bottom right). Spores with coats swollen in this manner were not observed with HL310. $|B|$ spiA $^{+}$spores $(\mathrm{HL} 310)$ after submersion at $10^{8}$ spores $/ \mathrm{ml}$ for 17 days. $(C)$ spiA ${ }^{-}$spores $(\mathrm{HL} 351)$ after submersion at $10^{8}$ spores $/ \mathrm{ml}$ for 17 days. Bar, $1 \mu \mathrm{m}$.

spores at the maximal level 7 days after the initiation of development. During the same developmental time course, the spiA mRNA first appeared at $22 \mathrm{hr}, \sim 2 \mathrm{hr}$ before the appearance of the $30-\mathrm{kD}$ protein (Fig. 8 ). The amount of mRNA was at a maximum at $24-26 \mathrm{hr}$, after which it dropped so that only a trace remained after 2 days and none was detectable after 3 days. Samples for each time point during development were prepared by grinding the collected fruiting bodies under liquid nitrogen in a mortar and pestle to ensure that both RNA and protein were efficiently extracted. The molecular mass predicted by translation of the spiA DNA sequence is 30,600 daltons (Richardson et al. 1991), which is consistent with the size of the protein recognized on Western blots. Because the appearance of the $30-\mathrm{kD}$ protein follows the accumulation of the spiA mRNA and the presence of the $30-\mathrm{kD}$ protein depends on an intact spiA gene, we conclude that the 506-3 sera is specific for Dd31, the spiA gene product.

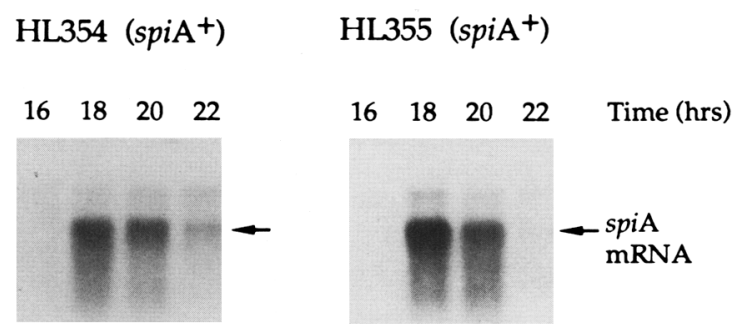

Figure 7. Developmental Northern blots of the rescued spiA ${ }^{+}$ strains HL354 and HL355. Northern blots were prepared from each strain as described in Fig. 3. Some cross-hybridization to the 1.9-kb rRNA was observed (just above the 1.4-kb spiA mRNA|.

\section{Localization of Dd31 in spores}

Spores from strain $\mathrm{Ax}-4$ were disrupted by grinding under liquid nitrogen and fractionated to investigate the subcellular localization of Dd31. The crude homogenate was centrifuged at $20,000 \mathrm{~g}$ for $15 \mathrm{~min}$, which yielded pellet and supernatant fractions. Analysis of these fractions on a Western blot with sera 506-3 indicated that Dd31 was present in the crude homogenate and the pellet but was not present in the supernatant (Fig. 9B and data not shown). The pellet was resuspended and separated by the two-phase method of Brunette and Till (1971), and the spore coat fragments were shown to partition to the interface by phase-contrast microscopy. Dd31 was present at the interface and absent in the pellet of the two-phase separation (Fig. 9B).

To investigate the stability of the association of Dd31 with the spore coat fragments, the fragments recovered from the interface were incubated in the presence of a number of detergents and centrifuged at $10,000 \mathrm{~g}$ for 15 min. This relatively low-speed centrifugation pellets the particulate spore coat fragments but would not pellet a soluble protein complex. Analysis of the protein in supernatants and pellets from each condition by Western blot revealed that neither $2 \%$ octyl glucoside, $5 \%$ CHAPS, $2 \%$ Triton X-100, nor $50 \mathrm{~mm}$ deoxycholate was effective in releasing Dd31 from the spore coat fragments (Table 1). Dd31 also remained with the fragments when incubated in $4 \mathrm{M} \mathrm{KCl}, 4 \mathrm{M}$ urea, or $4 \mathrm{~m}$ guanidine $\mathrm{HCl}$. The only conditions we found that were capable of releasing Dd31 were incubation with SDS or the chaotropic agent guanidine isothiocyanate. Treatment with SDS completely solubilized $\mathrm{Dd} 31$ at concentrations down to $0.1 \%$, and this solubilization did not require the addition of a reducing agent such as dithiothreitol.

Spore coat fragments that had been prepared by grind- 


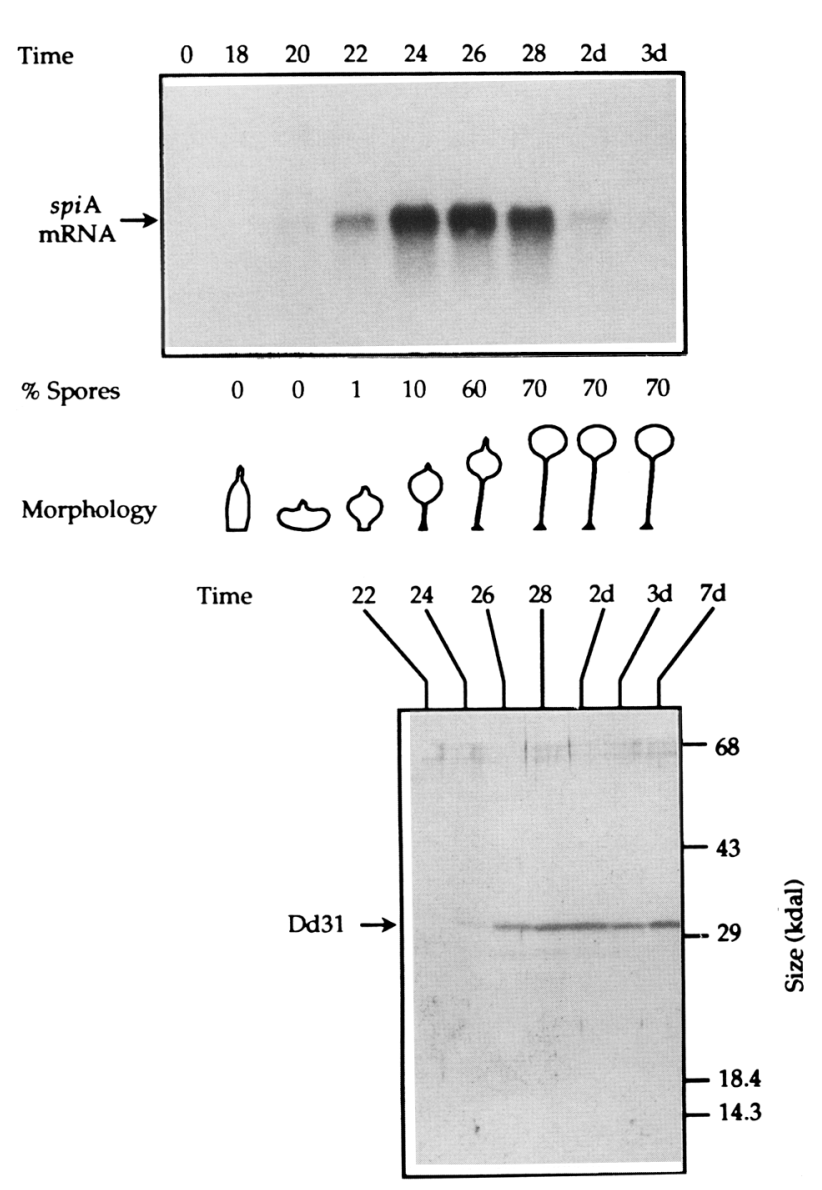

Figure 8. Developmental Northern and Western blots of $D$. discoideum strain Ax-4. Samples from each time point containing spores were collected in $20 \mathrm{~mm}$ EDTA and ground in a mortar and pestle under liquid nitrogen. The frozen sample was split, and RNA and protein were prepared and analyzed as described in Materials and methods. The percentage of spores seen at each time point is presented below the upper panel, along with a cartoon indicating the developmental stage. Northern blots were probed for spiA mRNA as in Fig. 3. Western blots were stained for Dd31 with antiserum 506-3 diluted 300-fold. The preimmune serum 506-0 did not bind to any Dictyostelium proteins on a Western blot of a similar time course.

ing spores, isolated by low-speed centrifugation, and fixed on poly-L-lysine-treated slides with methanol were analyzed for the presence of Dd31 in situ. Both the preimmune sera (506-0) and the Dd31-specific sera 506-3 weakly reacted with spore coat fragments from the spiA $^{-}$strain HL351 (data not shown), although neither of these sera would bind to any protein on Western blots of HL351 protein. To render the antisera specific to spiA, the serum was preadsorbed to spore coat fragments of the spiA $^{-}$strain HL351, which were then removed by centrifugation. Using the preadsorbed Dd31-specific sera 506-3, the spore coat fragments from HL310 fluoresced strongly, whereas spore coat fragments prepared in the same way from the spiA ${ }^{-}$strain HL351 did not fluoresce (Fig. 10). Phase contrast for each field is shown on the
$\mathrm{A}$

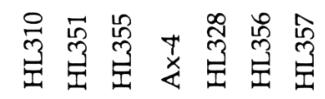

B

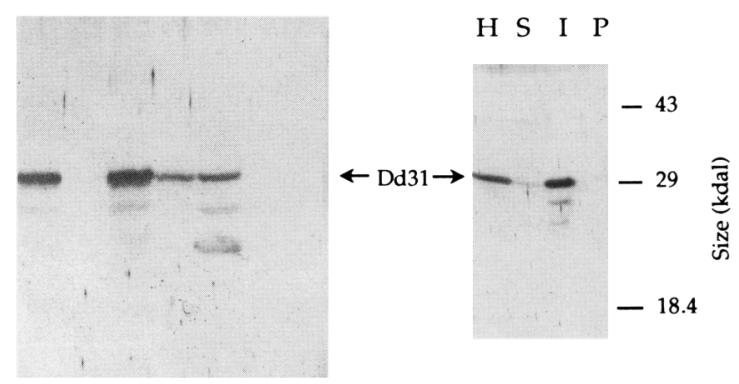

Figure 9. Western blots of spores and spore fractions stained for Dd31. Proteins solubilized from ground spores or spore fractions were electrophoretically separated, blotted, and stained as described in Fig. 8. (A) Analysis of spores from the strains indicated: HL351 is a spi ${ }^{-}$derivative of HL310; HL355 is a transformant of HL351 rescued with a spiA ${ }^{+}$vector; HL356 and HL357 are spiA ${ }^{-}$derivatives of HL328. (B) Analysis of Dd31 in fractionated spores. Spores of strain Ax-4 were disrupted by grinding under liquid nitrogen to form the crude lysate $(\mathrm{H})$. This material was centrifuged at $20,000 \mathrm{~g}$, and the supernatant $(\mathrm{S})$ was removed. The pellet, which was found to contain $\operatorname{Dd} 31$ in a previous experiment, was further fractionated by the two-phase separation of Brunette and Till (1971), and material was found at the interface $(\mathrm{I})$ and the pellet $(\mathrm{P})$. Five micrograms of protein from each fraction was loaded in each lane.

left. Under phase, spores are distinguished by a bright halo, whereas spore coats appear transparent with a dark edge. Unbroken spores in the sample of HL310 stained with antibody to Dd31 do not fluoresce, indicating that Dd31 is not exposed on the outer surface of the spore.

Table 1. Solubilization of Dd31 from spore coat fragments

\begin{tabular}{lc}
\hline Treatment & Soluble Dd31 (\%) \\
\hline None & 0 \\
$5 \%$ octyl glucoside & 10 \\
$2 \%$ CHAPS & 0 \\
$2 \%$ Triton X-100 & 10 \\
$50 \mathrm{mM} \mathrm{deoxycholate}$ & 0 \\
$4 \mathrm{M} \mathrm{KCl}$ & 0 \\
$4 \mathrm{M} \mathrm{urea}$ & 0 \\
$4 \mathrm{M}$ guanidine-HCl & 0 \\
$4 \mathrm{M}$ guanidine isothiocyanate (GITC) & 50 \\
$0.05 \%$ SDS & 75 \\
$0.1 \%$ SDS & 95 \\
$0.5 \%$ SDS & 100 \\
\hline
\end{tabular}

Spore coat fragments were incubated at $4^{\circ} \mathrm{C}$ for $60 \mathrm{~min}$ with the detergent indicated and centrifuged for $15 \mathrm{~min}$ at $10,000 \mathrm{~g}$ at $4^{\circ} \mathrm{C}$. The pellet was suspended in a volume equivalent to the supernatant, and equal volumes of pellet and supernatant fractions were analyzed by Western blot as described in Fig. 8 . The proportion solubilized was calculated by comparison of the relative intensity of both fractions for each condition. The sum of protein in the soluble and pellet fractions loaded on the gel was $10 \mu g$. 
Figure 10. Immunofluorescence of spore coat fragments and unbroken spores stained with antisera specific for $\mathrm{Dd} 31$ $(A, B)$ or SP96 $\{C \mid$. Samples were prepared from spores of the spiA ${ }^{+}$strain HL310 $(A)$ or the spiA ${ }^{-}$strain HL351 $(B, C)$ and analyzed as described in Materials and methods. The left panels show a view of a representative field under phase contrast; the right panels show fluorescence of the same field. Under phase, the intact spores are surrounded by a bright halo, whereas the spore coats are transparent with a dark outline. The antiserum against Dd31 (5063) was preadsorbed against HL351 fragments twice as described in Materials and methods.
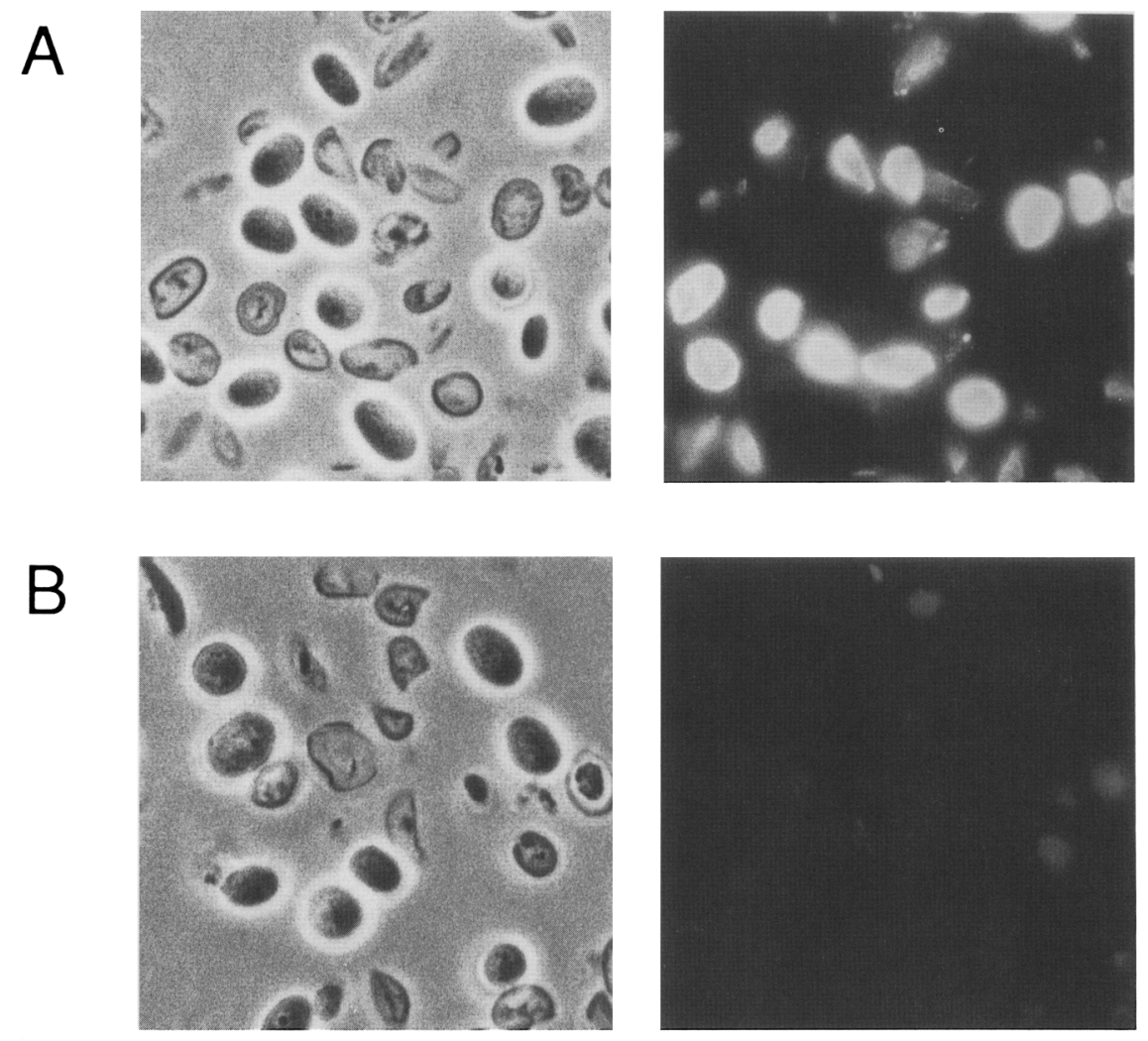

C

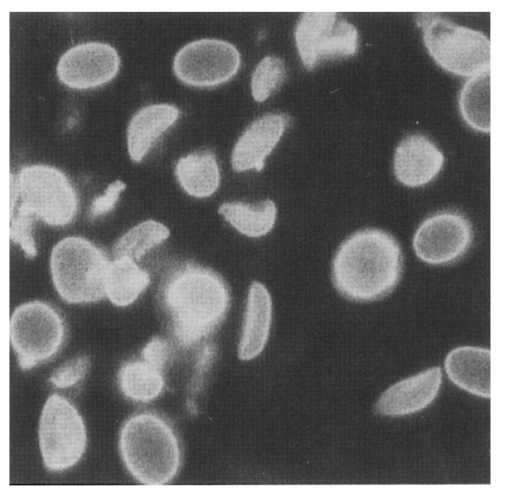

Antisera specific for the spore coat protein SP96 (Devine et al. 1983), which is present on the outer surface of the spore, recognize spore coat fragments and intact spores from HL351 and HL310 (Fig. 10 and data not shown). Spore coat fragments isolated from the rescued spiA ${ }^{+}$ strain HL355 that was derived from HL351 regained fluorescence (data not shown). The pattern of fluorescence indicates that $\mathrm{Dd} 31$ is spread across the inner surface of the coat fragments in HL310 and HL355 (Fig. 10).

\section{Discussion}

Disruption of the sporulation-specific spiA gene does not alter the course of culmination. Spores are formed that appear normal by scanning and transmission electron microscopy. The spore coats also appear normal. But the lack of the spiA gene product, Dd31, greatly reduces the stability of the resulting spores, such that viability is dramatically reduced after exposure to water. However, if the spores are dried before storage, their viability remains high. The altered phenotype was observed with mutant strains constructed in both Ax-2 and Ax-4 backgrounds, indicating that the phenotype is not peculiar to one strain. We also showed that replacement of a functional copy of the spiA gene resulted in the restoration of the wild-type phenotype, clearly indicating that the phenotype we have observed is due solely to the lesion in this specific gene. It is important to note that the presence of the deleted copy and the full-length copy of spiA in strains HL354 and HL355 proves that these are true 
rescued strains and not the result of accidental contamination with the parental wild-type strain. The rescued strains show normal temporal regulation of spiA, suggesting that all signals required for the correct temporal expression of the mRNA are present on the $4 \mathrm{~kb}$ of genomic DNA in the pLG4 Pyr vector that was used for the rescue.

We have used multiple rounds of selection to disrupt the spiA gene and then restore it by using selection for and against the UMP synthase gene pyr5-6, just as Kalpaxis et al. (1991) suggested should be possible. Interestingly, we were not able to use homologous recombination to replace the insert containing pyr5-6 and restore the wild-type gene directly by transforming with a linearized full-length gene and selecting with 5-fluoroorotic acid (5-FOA) (data not shown), although this is theoretically possible; other trials will be required to assess whether this is a general phenomena. Instead, we took the longer route of disrupting the pyr5-6 gene first and then restoring spiA and pyr5-6 in a second selection. The frequency of homologous recombination during the disruption of spiA was $70 \%$ in each of three trials (see Results; additional data not shown), even though there are equal regions of homology between the vector and the pyr5-6 and spiA genes.

When spiA was originally characterized, its mRNA was observed to accumulate and then disappear quite rapidly during culmination (Richardson et al. 1991). We postulated that the drop in the spiA message was the result of inefficient extraction of RNA from spores. By carefully extracting RNA from fruiting bodies, we have shown here that the spiA mRNA is not found in the mature spore, although it does not disappear completely until a couple of days after culmination is apparently complete. The product of the spiA gene must therefore be transcribed sometime during sporulation.

The product of the spiA gene, Dd31, has been identified as a $30-\mathrm{kD}$ protein on Western blots using a polyclonal antibody raised against a fusion protein containing the $5^{\prime}$ portion of the spiA gene. This $30-\mathrm{kD}$ protein appears during sporulation soon after the spiA mRNA is detected. The lack of this protein in spiA ${ }^{-}$strains and its reappearance when a functional copy of spiA was restored confirms that it is $\mathrm{Dd} 31$. In addition, expression of the $30-\mathrm{kD}$ protein is induced rapidly in cells from Mexican hat stage preculminants by the addition of $8-\mathrm{Br}-$ cAMP (data not shown), immediately after accumulation of the spiA message that is induced by $8-\mathrm{Br}-\mathrm{cAMP}(\mathrm{Ri}-$ chardson et al. 1991).

Dd31 is a component of the mature spore. It is associated in a detergent-resistant manner with the inner face of spore coats such that it can be reached by specific antibodies only when they are cracked or broken. The spore coats of mutant strains appear normal, with electron-dense inner and outer layers separated by a cellulosic middle layer, just as seen in the spore coats of the wild-type strains (Hohl and Hamamoto 1969; West and Erdos 1990). Mutations in the wetA gene of the filamentous fungus Aspergillis nigans also result in water-sensitive spores, but in this case the spores are missing two layers of the coat (Sewall et al. 1990). Expression of the wet A gene during growth has shown that it controls the expression of a number of spore-specific genes (Marshall and Timberlake 1991). The presence of Dd31 in the spore coat suggests that it is a structural component rather than a regulator of gene expression.

The absence of Dd31 does not alter the structure of the spore coat that we observe by electron microscopy, but the increased sensitivity to water makes it clear that something is different. One possibility is that a lack of Dd31 subtly alters the structure of the coat such that water can penetrate in a nonspecific manner. Another possibility is that $\mathrm{Dd} 31$ directly blocks the intrusion of water. The primary sequence of $\mathrm{Dd} 31$ was distinguished by four regions that were extremely hydrophobic, on the basis of which we postulated a transmembrane location for the protein (Richardson et al. 1991). Perhaps Dd31 forms a plug or gate that excludes water by blocking pores. Such pores might be present to allow swelling, a normal event in activated spores that occurs prematurely in germination-inhibited spiA ${ }^{-}$spores. Activation of germination dramatically affects the properties of spore coats, and it is an intriguing possibility that $\mathrm{Dd} 31$ may be a central player in this process.

\section{Materials and methods}

Strains, growth conditions, and development

D. discoideum strain HL310 is a ura- derivative of Ax-2 owing to a deletion in pyr5-6; it was originally named $\Delta 16-11$ (Kalpaxis et al. 1991). Strain HL328 is a pyr5-6 derivative of Ax-4 prepared by Dr. Adam Kuspa in our laboratory. The axenic strains $\mathrm{Ax}-2$ and Ax-4 were isolated independently from NC-4 (Watts and Ashworth 1970; Loomis 1971; Knecht et al. 1986). Cells were grown axenically in HL5 media, washed, and deposited on buffered nitrocellulose filters for development as described by Sussman (1987). Lyophils were prepared with bacterially grown spores, which were suspended in nonfat milk, transferred to tubes, dried by lyophilization, and sealed under vacuum (Sussman 1987). Lyophils were stored at $4^{\circ} \mathrm{C}$.

\section{Plasmid constructions}

The plasmid pDU3B1, which contains the entire $D$. discoideum pyr5-6 gene on a $3.7-\mathrm{kb}$ Clal fragment, was generously provided by Dr. T. Dingermann (Boy-Marcotte et al. 1984; Kalpaxis et al. 1991). This ClaI fragment was inserted into AccI-digested pGEM-3 (Promega) in both orientations to make the plasmids DIV-1 and DIV-2 (K. Fosnaugh, pers. comm.). The insert in DIV-1 is oriented so that digestion with HindIII will excise a $3.7-\mathrm{kb}$ fragment containing pyr5-6, whereas the same digestion of DIV-2 will excise a short region of the multiple cloning site.

Plasmid pLG4 contains $4 \mathrm{~kb}$ of genomic DNA spanning the spiA gene (Richardson et al. 1991). To construct the gene replacement vector $\mathrm{pKD} 31-3$, a $4.7-\mathrm{kb}$ fragment of SpeI/PstI-digested pLG4 was purified away from a 450-bp fragment within spiA. The larger fragment was ligated to a $3.7-\mathrm{kb} X b a I-P s t \mathrm{I}$ fragment of DIV-2 containing the pyr5-6 gene, using compatable cohesive ends (Fig. 1). The rescue vector pLG4 Pyr is also based on pLG4. Here, a 5.3-kb BamHI-Bgll fragment of DIV-1 was combined with a $5.6 \mathrm{~kb}$ BamHI-BgII fragment of pLG4. This puts the pyr5-6 gene next to the 4 -kb genomic DNA containing 
the spiA gene. Athough BgII cuts in the ampicillin resistance gene of the pGEM plasmids, fusion of the two fragments regenerates the gene.

\section{Transformations}

Cells were transformed by electroporation as described by Howard et al. (1988), except that the cells were not washed prior to being suspended in the Zap buffer. Electroporations were performed using $10 \mu \mathrm{g}$ of plasmid on a Bio-Rad gene pulser at 2.5 $\mathrm{kV} / \mathrm{cm}$ at a capacitance of $3 \mu \mathrm{F}$. pyr5- $6^{+}$transformants were selected by growth in minimal media, or FM (Franke and Kessin 1977), whereas pyr5-6 ${ }^{-}$transformants were selected by growth in HL-5 containing 5-FOA as described by Kalpaxis et al. (1990, 1991). After growth in the selective media, transformants were plated at low density on SM agar plates in association with Klebsiella aerogenes (Sussman 1987). Single colonies were picked into HL-5 containing $100 \mathrm{U} / \mathrm{ml}$ each of penicillin $\mathrm{G}$ and streptomycin sulfate (Pen-Strep) for growth and analysis.

\section{Dot blots and genomic minipreps}

Transformants could be screened rapidly by growing them in HL5 to a titer of $1 \times 10^{6}$ to $5 \times 10^{6}$ cells $/ \mathrm{ml}$ and collecting 0.2 $\mathrm{ml}$ of each culture on a nitrocellulose membrane by suction through a manifold. Cells were lysed and their DNA fixed on the membrane as described previously for bacteria by Grunstein and Hogness (1975). The membranes were hybridized, washed, and exposed as described for Southern blots (see below).

Genomic miniprep DNA was prepared from $25 \mathrm{ml}$ of culture at a density of $1 \times 10^{6}$ to $5 \times 10^{6}$ cells $/ \mathrm{ml}$. Nuclei were isolated as described previously (Richardson et al. 1991), and $40 \mu \mathrm{l}$ of nuclei were lysed by the addition of $200 \mu \mathrm{l}$ water and $60 \mu \mathrm{l}$ of 0.5 M EDTA. After mixing, $200 \mu \mathrm{l}$ of $10 \%$ Sarcosyl was added, and the lysate was mixed again and incubated for $5 \mathrm{~min}$ at $60^{\circ} \mathrm{C}$. The DNA solution was then extracted twice with phenol-chloroform, extracted once with chloroform, and precipitated by the addition of $1 \mathrm{ml}$ of ethanol.

\section{Viability assays}

The viability of spores was determined by suspending them in

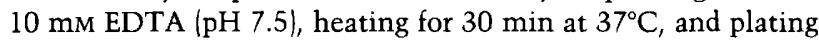
at various dilutions in association with $K$. aerogenes (Morrissey and Loomis 1981). Two or four dilution series were prepared for each sample. The percent viability was calculated by comparing the number of colony-forming units observed to the number of phase-bright spores plated. The concentration of phase-bright spores was determined by microscopy.

To analyze the stability of spores while submerged, they were collected after growth in association with $K$. aerogenes and subsequent development by rapping inverted plates against the counter, and collecting the spores from the lid. The spores were diluted to $1.5 \times 10^{8} / \mathrm{ml}$, and phosphate buffer $(\mathrm{pH} 6.4)$ was added to $1 \mathrm{~mm}$. Pen-Strep was added to $100 \mathrm{U} / \mathrm{ml}$ to retard bacterial growth, and the suspension was shaken at $100 \mathrm{rpm}$ at $22^{\circ} \mathrm{C}$ for the course of the assay. Spores were routinely collected 5 days after the initial plating, which allowed the completion of culmination across the plate but did not allow spores to age more than 1 day before the assay began. Viability was assayed as described above, and the initial concentration of phase-bright spores was used to calculate the percentage viability throughout the experiment.

\section{Southern blots, Northern blots, and probes}

Southern and Northern blots were prepared and probed with riboprobe for spiA (Dd31) as described previously (Richardson et al. 1991). For DNA probes, isolated DNA fragments were labeled with $\left[\alpha-{ }^{32} \mathrm{P}\right] \mathrm{dCTP}$ by random hexamer-primed DNA synthesis (Feinberg and Vogelstein 1983). After hybridization under the same conditions used for riboprobes, blots were washed three times for $30 \mathrm{~min}$ each with $0.5 \times \mathrm{SSPE}$ and $0.05 \%$ sodium lauryl sarcosylate at $55^{\circ} \mathrm{C}$. Blots were stripped between probings by washing twice for $30 \mathrm{~min}$ in $0.1 \times$ SSPE and $0.05 \%$ sodium lauryl sarcosylate at $75^{\circ} \mathrm{C}$.

\section{Electron microscopy}

Spores were prepared for transmission electron microscopy essentially as described by Loomis (1975), except that they were fixed for $2 \mathrm{hr}$ on ice in $2.5 \%$ glutaraldehyde, $2 \%$ paraformaldehyde. Spores were treated with $1 \%$ osmium, dehydrated, embedded in Spurr's resin, and sectioned. Grids were poststained with $2 \%$ uranyl acetate followed by Reynold's lead citrate. For scanning electron microscopy, spores were fixed, osmicated, dehydrated as described above, and critical point dried. Samples were gold coated and viewed on a Hitachi 405-A scanning scope.

\section{spiA fusion constructs and expression in $\mathrm{E}$. coli}

The plasmid pLGcl contains a clone of a spiA cDNA that was amplified by PCR (Richardson et al. 1991). To construct pLGc3, the region of DNA containing the spliced joint from pLGcl was moved into the $1-\mathrm{kb}$ EcoRI fragment of pLG2, which contains most of the coding sequence of spiA (Richardson et al. 1991). This was accomplished by replacement of the 621-bp SstI-NcoI fragment of pLG2 with the 438-bp SstI-NcoI fragment from pLGcl.

To make the fusion construct pGX4, the 850 -bp EcoRI fragment of pLGc3 was gel purified, HinfI digested, and blunted with Klenow. BamHI linkers (5'-CGCGGATCCGCG-3', New England Biolabs no. 1065/ were ligated to the mixture of fragments, which regenerated the EcoRI site, and the fragments were digested with EcoRI and BamHI. The 233-bp fragment was isolated and ligated into EcoRI/BamHI-digested pGEMEX1. Thus, pGX4 has a fusion of 77 amino acids of spiA from the carboxy-terminal region of the protein to the first 269 amino acids of the $\mathrm{T} 7$ gene 10 protein.

Two other constructs were made that contained a larger portion of the coding region from $\mathrm{pLGc3}$ fused to the $\mathrm{T} 7$ gene 10 protein, but their fusion proteins could not be overexpressed at high level in $E$. coli, perhaps owing to the presence in these constructs of DNA encoding some or all of the four hydrophobic regions at the 3' end of the protein. Interestingly, when expression was induced in cultures carrying the longer constructs, growth was completely attenuated, whereas stains containing pGX4 or pGEMEX1 continued to grow after induction.

Subcloning was performed in E. coli $\mathrm{DH} 5 \alpha$ (GIBCO BRL) to avoid any potential negative selection as a result of background expression of the fusion constructs during growth. The fusion plasmids were then transferred into E. coli BL21(DE3) containing pLysS for expression of the fusion protein (Studier 1991). $B L 21(D E 3)$ is a lysogen of DE3, a phage $\lambda$ derivative that contains the gene for the T7 RNA polymerase under the control of the lacUV5 promoter (Studier et al. 1990). Background expression of the T7 RNA polymerase is controlled by the plasmid pLysS, which expresses T7 lysozyme at a low level; T7 lysozyme is a natural inhibitor of the T7 RNA polymerase (Studier 1991). Growth, determination of plasmid titers, and 
induction of fusion protein expression were performed as described previously (Studier et al. 1990). Induced strains were allowed to accumulate fusion protein for 3-4 hr.

Inclusion bodies were isolated as described previously (Kleid et al. 1981), except that a simple freeze-thaw was used to release the endogenous lysozyme for lysis of the bacteria. Protein from inclusion bodies was solubilized, separated by SDS-PAGE, and stained as described previously (Richardson et al. 1988). The 506 antiserum was prepared by subcutaneous and intradermal injection into a female New Zealand rabbit of $\sim 100 \mu \mathrm{g}$ of Dd31 fusion protein from a gel slice that was emulsified in Freund's complete adjuvant. The rabbit was boosted twice at monthly intervals with an additional $50 \mu \mathrm{g}$ of $\mathrm{Dd} 31$ fusion protein, and serum was collected 10 days after each boost. The second batch of serum, 506-2, reacted with Dd31 on Western blots. After several months, the rabbit was boosted as before and the serum that was used for these experiments was collected (506-3).

\section{Western blots and immunofluorescence}

After separation by SDS-PAGE, proteins were transferred to nitrocellulose and incubated with primary and secondary antibodies as described previously (Knecht and Loomis 1987). The primary antibody, 506-3, was diluted 300 -fold before use. The secondary antibody was goat anti-rabbit IgG conjugated to alkaline phosphatase (Sigma). Alkaline phosphatase activity was visualized by staining with 5-bromo-4-chloro-3-indoyl phosphate (BCIP) and nitroblue tetrazolium (NBT) as described previously (Blake et al. 1984).

For the immunofluorescence, spores suspended in $10 \mathrm{~mm}$ Tris- $\mathrm{HCl}$ (pH 7.5), $1 \mathrm{~mm}$ EDTA, and $150 \mathrm{~mm} \mathrm{NaCl}$ (TEN) were broken by grinding in liquid nitrogen, and the spore coat fragments and unbroken spores were pelleted by centrifugation at $20,000 \mathrm{~g}$ for $15 \mathrm{~min}$. The pellet was washed once and then suspended in the same buffer. The mixture of spore coat fragments and unbroken spores was fixed on poly-L-lysine-coated slides with $-20^{\circ} \mathrm{C}$ methanol for $10 \mathrm{~min}$, washed twice with $10 \mathrm{~mm}$ Tris- $\mathrm{HCl}(\mathrm{pH} 7.5)$ and buffered saline (TBS), and blocked with $10 \%$ fetal calf serum (FCS) in TBS for $10 \mathrm{~min}$. Slides were incubated with antisera diluted 10 -fold in $10 \%$ FCS-TBS for 30 min, washed three times with TBS, incubated with FITC conjugated to goat anti-rabbit antibody (Boeringer Mannheim) diluted $1: 100$ in $10 \%$ FCS-TBS for an additional $30 \mathrm{~min}$, and washed three times with TBS. The sample was covered with 0.1 $\mathrm{mg} / \mathrm{ml}$ of phenyldiamine in $10 \mathrm{~mm}$ Tris- $\mathrm{HCl} / \mathrm{pH} 8.5 \mid, 90 \%$ glycerol, and visualized by phase-contrast and fluorescence microscopy with a $100 \times$ objective. The antibody to $\operatorname{Dd} 31,506-3$, and the preimmune bleed, 506-0, were each preadsorbed to spore coat fragments of the spiA ${ }^{-}$strain HL351. Each antiserum was diluted $1: 4$ in TBS and incubated with fragments for 2-3 hr at $4^{\circ} \mathrm{C}$, after which the fragments were removed by centrifugation. The preadsorbtion was repeated once with an overnight incubation. After this treatment, the preimmune bleed did not react with HL310 or HL351 spore coat fragments in situ.

\section{Acknowledgments}

We thank Dr. T. Dingermann for sharing vectors and protocols prior to publication, Dr. A. Kuspa for vectors and help with the 5-FOA selections, and Dr. K. Fosnaugh for vector constructions. We thank Dr. V. Malhotra and Ms. B. de Champlon for suggestions and protocols for the immunofluorescence, Mr. L. Washington for the electron microscopy, and Dr. A. Grens for critically reading the manuscript. This work was supported by a grant from the National Institutes of Health (GM 23822).
The publication costs of this article were defrayed in part by payment of page charges. This article must therefore be hereby marked "advertisement" in accordance with 18 USC section 1734 solely to indicate this fact.

\section{References}

Abe, H., M. Uchiyama, Y. Tanaka, and H. Saito. 1976. Structure of discadenine, a spore germination inhibitor from the cellular slime mold, Dictyostelium discoideum. Tetrahedron Lett. 42: 3807-3810.

Blake, M., K. Johnson, G. Russel-Jones, and E. Gotschlich. 1984. A rapid sensitive method for detection of alkaline phosphatase-conjugated anti-antibody on Western blots. Anal. Biochem. 136: 175-179.

Blume, J.E. and H.L. Ennis. 1991. A Dictyostelium discoideum cellulase is a member of a spore germination-specific gene family. J. Biol. Chem. 266: 15432-15437.

Boy-Marcotte, E., F. Vilaine, J. Camonis, and M. Jacquet. 1984. A DNA sequence from Dictyostelium discoideum complements ura3 and ura5 mutations of Saccharomyces cerevisiae. Mol. ↔) Gen. Genet. 193: 406-413.

Brunette, D.M. and J.E. Till. 1971. A rapid method for the isolation of L-cell surface membranes using an aqueous twophase polymer system. I. Membrane Biol. 5: 215-224.

Cohen, A. and C. Ceccarini. 1967. Inhibition of spore germination in the cellular slime molds. Ann. Bot. 31: 479-487.

Cotter, D.A. and K.B. Raper. 1968. Properties of germinating spores of Dictyostelium discoideum. I. Bacteriol. 96: 16801689.

Cotter, D.A., L.Y. Miura-Santo, and H.R. Hohl. 1969. Ultrastructural changes during germination of Dictyostelium discoideum. J. Bacteriol. 100: 1020-1026.

Devine, K.M., J.E. Bergmann, and W.F. Loomis. 1983. Spore coat proteins of Dictyostelium discoideum are packaged in prespore vesicles. Dev. Biol. 99: 437-446.

Erdos, G.W. and C.M. West. 1989. Formation and organization of the spore coat of Dictyostelium discoideum. Exp. Mycol. 13: $169-182$.

Feinberg, A.P. and B. Vogelstein. 1983. A technique for radiolabeling DNA restriction endonuclease fragments to high specific activity. Anal. Biochem. 132: 6-13.

Franke, J. and R. Kessin. 1977. A defined minimal medium for axenic strains of Dictyostelium discoideum. Proc. Natl. Acad. Sci. 74: 2157-2161.

George, R.P., H.R. Hohl, and K.B. Raper. 1972. Ultrastructural development of stalk producing cells in Dictyostelium discoideum, a cellular slime mould. J. Gen. Microbiol. 70: 477489

Grunstein, M. and D. Hogness. 1975. Colony hybridization: A method for the isolation of cloned DNAs that contain a specific gene. Proc. Natl. Acad. Sci. 72: 3961-3965.

Hohl, H.R. and S.T. Hamamoto. 1969. Ultrastructure of spore differentiation in Dictyostelium: The prespore vacuole. $J$. Ultrastruct. Res. 26: 442-453.

Howard, P.K., K.G. Ahern, and R.A. Firtel. 1988. Establishment of a transient expression system for Dictyostelium discoideum. Nucleic Acids Res. 16: 2613-2623.

Jones, T.H.D., M. De Renobales, and N. Pon. 1979. Cellulases released during the germination of Dictyostelium discoideum spores. I. Bacteriol. 137: 752-757.

Kalpaxis, D., H. Werner, E. Boy-Marcotte, M. Jacquet, and T. Dingermann. 1990. Positive selection for Dictyostelium mutants lacking uridine monophosphate synthase activity based on resistance to 5-fluoro-orotic acid. Dev. Genet. 
11: 396-402.

Kalpaxis, D., I. Zundorf, H. Werner, N. Reindl, E. Boy-Marcotte, M. Jacquet, and T. Dingermann. 1991. Positive selection for Dictyostelium discoideum mutants lacking UMP synthase activity based on resistance to 5-fluoroorotic acid. Mol. 4$)$ Gen. Genet. 225: 492-500.

Kay, R.R. 1989. Evidence that elevated intracellular cyclic AMP triggers spore maturation in Dictyostelium. Development 105: 753-759.

Kleid, D.G., D. Yansura, B. Small, D. Dowbenko, D.M. Moore, M.J. Grubman, P.D. McKercher, D.O. Morgan, B.H. Robertson, and H.L. Bachrach. 1981. Cloned viral protein vaccine for foot-and-mouth disease: Responses in cattle and swine. Science 214: 1125-1129.

Knecht, D.A. and W.F. Loomis. 1987. Antisense RNA inactivation of myosin heavy chain gene expression in Dictyostelium discoideum. Science 236: 1081-1086.

Knecht, D.A., S.M. Cohen, W.F. Loomis, and H.F. Lodish. 1986. Developmental regulation of Dictyostelium discoidum actin gene fusions carried on low-copy and high-copy transformation vectors. Mol. Cell. Biol. 6: 3973-3983.

Kuspa, A., D. Maghakian, P. Bergesh, and W.F. Loomis. 1992. Physical mapping of genes to specific chromosomes in Dictyostelium discoideum. Genomics 13 (in press).

Loomis, W.F. 1971. Sensitivity of Dictyostelium discoideum to nucleic acid analogues. Exp. Cell Res. 64: 484-486.

. 1975. Dictyostelium discoideum: A developmental system. Academic Press, New York.

Marshall, M.A. and W.E. Timberlake. 1991. Aspergillus nidulans wetA activates spore-specific gene expression. Mol. Cell. Biol. 11: 55-62.

Morrissey, J.H. and W.F. Loomis. 1981. Parasexual genetic analysis of cell proportioning mutants of Dictyostelium discoideum. Genetics 99: 183-196.

Morrissey, J.H., P.A. Farnsworth, and W.F. Loomis. 1981. Pattern formation in Dictyostelium discoideum: An analysis of mutants altered in cell proportioning. Dev. Biol. 83: 1-8.

Orlowski, M. and W.F. Loomis. 1979. Plasma membrane proteins of Dictyostelium: The spore coat proteins. Dev. Biol. 71: 297-307.

Richardson, D.L., A. Aoyama, and M. Hayashi. 1988. Proteolysis of the bacteriophage $\phi \times 174$ prohead protein $\mathrm{gpB}$ by a protease located in the Escherichia coli outer membrane. $J$. Bacteriol. 170: 5564-5571.

Richardson, D.L., C.B. Hong, and W.F. Loomis. 1991. A prespore gene, Dd31, expressed during culmination of Dictyostelium discoideum. Dev. Biol. 144: 269-280.

Sewall, T., C.W. Mims, and W.E. Timberlake. 1990. Conidial differentiation in wild type and wet $\mathrm{A}^{-}$strains of Aspergillus nidulans. Dev. Biol. 138: 499-508.

Studier, F.W. 1991. Use of bacteriophage T7 lysozyme to improve an inducible $\mathrm{T} 7$ expression system. I. Mol. Biol. 219: 37-44.

Studier, F.W., A.H. Rosenberg, J.J. Dunn, and J.W. Dubendorff. 1990. Use of T7 RNA polymerase to direct expression of cloned genes. Methods Enzymol. 185: 60-89.

Sussman, M. 1987. Cultivation and synchronous morphogenesis of Dictyostelium under controlled experimental conditions. Methods Cell Biol. 28: 9-29.

Watts, D. and J. Ashworth. 1970. Growth of myxamoebae of the cellular slime mould Dictyostelium discoideum in axenic culture. Biochem. J. 119: 171-174.

West, C.M. and G.W. Erdos. 1990. Formation of the Dictyostelium spore coat. Dev. Genet. 11: 492-506. 


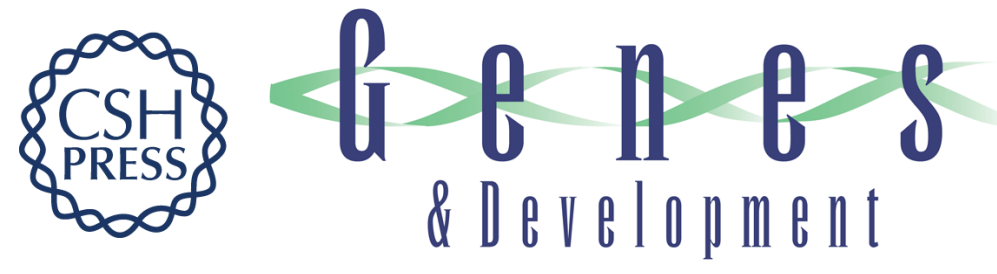

\section{Disruption of the sporulation-specific gene spiA in Dictyostelium discoideum leads to spore instability.}

D L Richardson and W F Loomis

\section{Genes Dev. 1992, 6:}

Access the most recent version at doi:10.1101/gad.6.6.1058

References This article cites 36 articles, 14 of which can be accessed free at: http://genesdev.cshlp.org/content/6/6/1058.full.html\#ref-list-1

License

Email Alerting

Service

Receive free email alerts when new articles cite this article - sign up in the box at the top right corner of the article or click here.

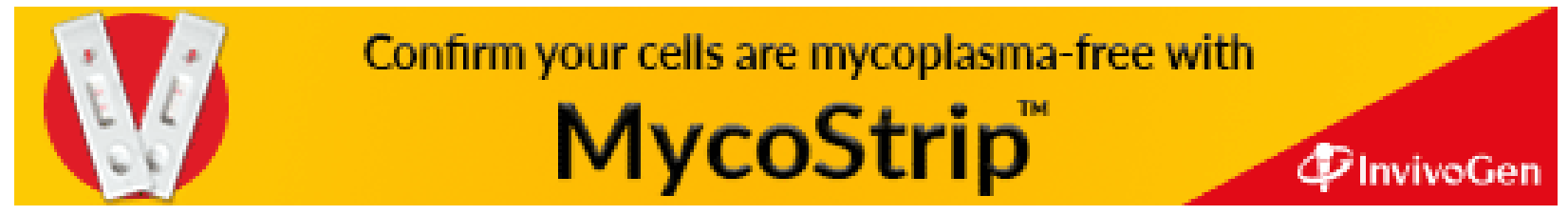

